\title{
Analisa Hubungan Panjang dengan Berat Ikan Bawal Bintang (Trachinotus Blochii, Lacepede) Pada Sistem Keramba Jaring Apung (KJA) Integrated Multi Trophic Aquaculture (IMTA) di Kawasan Sea Farming Kepulauan Seribu
}

\author{
Diana Nasti, Sunarno dan Sapto. P. Putro \\ Magister Biologi, Fakultas Matematika dan Sains (FSM) \\ Universitas Diponegoro Jl. Prof. H. Sudharto, Tembalang, Semarang
}

\begin{abstract}
Abstrak
Tujuan penelitian ini adalah menganalisa hubungan panjang dan berat ikan bawal bintang (Trachinotus blochii) pada sistem keramba jaring apung (KJA) Integrated multi trophic aquaculture (IMTA) dan Monokultur. Keramba jaring apung IMTA diaplikasikan pada Stratified double net cage (SDNC). Penelitian ini dilakukan di kawasan Sea Farming Karang Lebar kepulauan Seribu, di dua lokasi yaitu : lokasi A adalah kawasan budidaya sistem IMTA dengan jenis biota ikan bawal bintang (Trachinotus blochii) dan ikan kerapu macan (Epinephelus fuscoguttatus, Forsskal). Lokasi B adalah kawasan budidaya monokultur dengan jenis biota bawal bintang (Trachinotus Blochii). Hasil penelitian analisa hubungan panjang dan berat ikan di kedua lokasi menunjukan pola alometrik positif $\mathrm{b}>3$, dan berdasarkan kondisi fisik dan kimia perairan laut dari kedua lokasi penelitian terdapat perbedaan namun, secara umum masih menunjukkan dalam kisaran normal yaitu konduktivitas berkisar antara 4,53 - 5,05 mS/cm, kecerahan berkisar antara 23,21 - 25,50 mg/l, turbiditas berkisar antara 19,89-27,00 mg/l, Dissolved Oxygen (DO) berkisar pada 6,09 - 7,50 mg/L, salinitas berkisar antara 25,09 - 32,37ppt, pH berkisar antara 7,21 7,96 dan temperatur berkisar antara $29,33-31,40{ }^{\circ} \mathrm{C}$.
\end{abstract}

Kata kunci : Bawal bintang (Trachinotus blochii), IMTA, Monokultur, pola pertumbuhan 


\section{PENDAHULUAN}

Budidaya merupakan salah satu upaya untuk meningkatkan produksi perikanan, terutama untuk jenis biota bernilai ekonomis penting. Salah satu usaha budidaya yang sampai saat ini dianggap cukup efektif karena tidak membutuhkan banyak lahan di darat adalah sistem budidaya dalam keramba jaring apung (KJA). Jenis ikan yang dibudidayakan dengan sistem KJA ini adalah ikan bawal bintang (Trachinotus blochii) dan ikan kerapu macan (Epinephelus fuscoguttatus). Faktor yang sangat berpengaruh terhadap pertumbuhan ikan budidaya adalah pakan. Pakan yang berkualitas baik merupakan faktor penting penentu keberhasilan budidaya ikan secara intensif seperti dalam sistem KJA. Analisa hubungan panjang dengan berat bertujuan untuk mengetahui pola pertumbuhan ikan dengan menggunakan parameter panjang dan berat. Berat dianggap sebagai satu fungsi dari panjang. Nilai yang didapat dari perhitungan panjang dengan berat dapat digunakan sebagai pendugaan berat dari panjang. Selain itu, keterangan mengenai pertumbuhan, bobot, dan perubahan lingkungan terhadap ikan dapat diketahui (Effendie, 1997).

Integrated multi trophic aquaculture (IMTA) adalah suatu metode untuk mengoptimalkan hasil perikanan melalui pemanfaatan sistem budidaya dengan pendekatan alamiah ekosistem laut sehingga mengopimalkan hasil, efesiensi pakan dan diversifikasi produk. Menurut Barrington (2009) Sistem IMTA merupakan praktik budidaya dengan lebih dari 1 kultivar atau polikultur yang memiliki hubungan mutualistik secara ekologis sebagai satu rantai makanan pada area atau sistem yang sama dalam waktu yang bersamaan. IMTA mulai diterapkan sebagai solusi terhadap mitigasi limbah yang dikeluarkan dalam marikultur, akibat peningkatan efesiensi dari pakan sehingga tidak mencemari lingkungan. IMTA dapat digunakan hampir di seluruh wadah budidaya, baik laut maupun darat karena konsep keseimbangan ekosistem yang diterapkan (Putro et al, 2015). Pengukuran bobot biomassa maupun bobot per ekor ikan dilakukan setiap 2 minggu sekali selama 6 bulan pemeliharaan. Sedangkan parameter kualitas air yang diukur antara lain; konduktivitas, turbiditas, kecerahan, suhu, $\mathrm{pH}$, DO dan salinitas

\section{BAHAN DAN METODE}

Secara garis besar penelitian ini dilakukan dengan pemeliharaan ikan dalam keramba jaring apung bertingkat sistem IMTA. Data yang digunakan dalam penelitian ini adalah data primer, diambil dari hasil pengukuran serta penimbangan panjang dan berat ikan bawal bintang dan ikan kerapu macan di lokasi penelitian. Data diambil setiap dua minggu sekali kemudian ikan ditimbang (g) dan diukur panjangnya $(\mathrm{cm})$ sebanyak 10 ekor, lalu dicatat pada data sheet. Pengambilan data berat dan panjang ikan sangat penting untuk mendapatkan nilai laju pertumbuhan ikan. Berat dapat dianggap sebagai suatu fungsi dari panjang. Hubungan panjang dengan berat dapat diketahui dengan rumus (Effendie 1997).

$$
\mathbf{W}=\mathbf{a} \mathbf{L}^{\mathbf{b}}
$$

Keterangan: W yaitu berat ikan (g), L yaitu panjang total ikan $(\mathrm{cm}), \mathrm{a}, \mathrm{b}$ yaitu konstanta. Jika rumus umum tersebut ditransformasikan dengan logaritma, maka akan didapatkan persamaan linie atau persamaan garis lurus sebagai berikut :

\section{$\log W=\log a+b \log L$}

Analisis hubungan panjang dengan berat bertujuan mengetahui pola pertumbuhan dengan menggunakan parameter panjang dan berat ikan (Effendie, 1997). Untuk mendapatkan parameter a dan $b$, digunakan analisis regresi dengan log W sebagai ' $y$ ' dan Log L sebagai ' $x$ ', maka didapatkan persamaan regresi :

$$
\mathbf{y}=\mathbf{a}+\mathbf{b x}
$$

Untuk menguji nilai $b=3$ atau $b \neq 3$ dilakukan uji-t (uji parsial), dengan hipotesis

$\mathrm{H} 0: \mathrm{b}=3$, hubungan panjang dengan berat adalah isometrik. $\mathrm{H} 1: \mathrm{b} \neq 3$, hubungan panjang dengan berat adalah allometrik, yaitu : Allometrik positif, jika $\mathrm{b}>3$ (pertambahan berat lebih cepat dari pada pertambahan panjang) dan, Allometrik negatif, jika $\mathrm{b}<3$ (Pertambahan panjang lebih cepat dari pada pertambahan berat), (Steel and Torie, 1993 dalam Effendie, 1997) .

\section{HASIL DAN PEMBAHASAN}

Analisa hubungan panjang dengan berat ikan bawal bintang (Trachinotus blochii) dan kerapu macan (Epinephelus fuscoguttatus) 
pada waktu pengukuran dan penimbangan di kedua lokasi penelitian, didapatkan hasil seperti yang terlihat pada Gambar berikut :

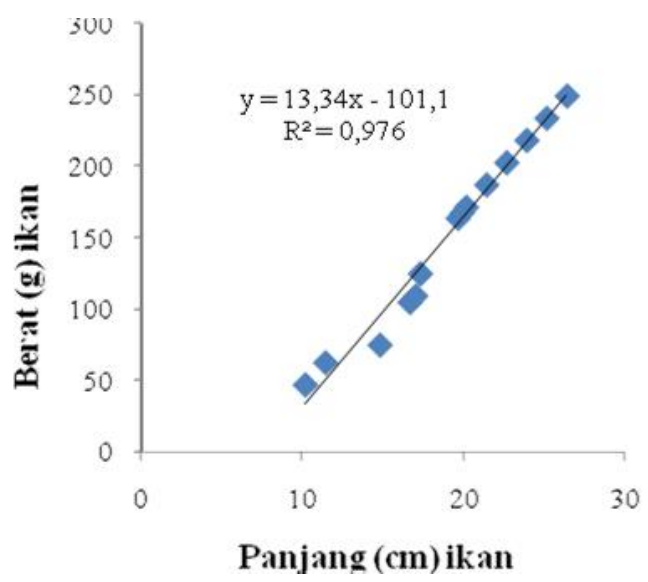

Gambar 1. Grafik laju pertumbuhan hubungan panjang dengan berat ikan bawal bintang pada budidaya KJA IMTA

Hubungan panjang dengan berat ikan bawal bintang yang diperoleh dari sekitar kawasan sea farming pada budidaya KJA IMTA mengikuti persamaan $W=W(t)=13,34 \times L 101,1 \mathrm{deng}$ an koefisien korelasi $R^{2} 0,976$. Hal ini menunjukan tingkat kepercayaan terhadap model ini sebesar 97,6\%. Hasil analisis regresi

linear menghasilkan persamaan $Y=13,34 x-101,1$ sehingga didapat nilai $b$ adalah 13,34 . Setelah dilakukan uji $t$ pada selang kepercayaan 95\%, diputuskan bahwa nilai $b$ sebesar 13,34 bersifat alometrik positif, dengan kata lain, laju pertumbuhan berat ikan bawal bintang di sekitar kawasan sea farming lebih dominan dibandingkan dengan laju pertumbuhan panjangnya.

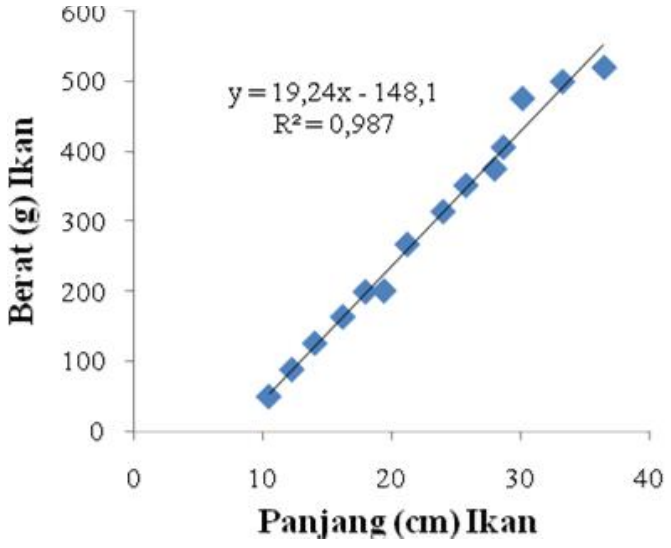

Gambar 2. Grafik laju pertumbuhan hubungan panjang dengan berat ikan bawal bintang pada budidaya KJA monokultur.

Hubungan panjang dengan berat ikan bawal bintang yang diperoleh dari sekitar kawasan Sea Farming pada budidaya KJA IMTA mengikuti persamaan $W=19,24 x-148,1 \quad$ dengan koefisien korelasi $R^{2}=0,987$. Hal ini menunjukan tingkat kepercayaan terhadap model ini sebesar 98,7\%. Hasil analisis regresi linear menghasilkan persamaan $Y=19,24 \mathrm{x}-148,1$ sehingga didapat nilai $b$ adalah 19,24 Setelah dilakukan uji $t$ pada selang kepercayaan $95 \%$, diputuskan bahwa nilai $b$ sebesar 19,24 bersifat alometrik positif, dengan kata lain, laju pertumbuhan berat ikan bawal bintang di sekitar kawasan sea farming lebih dominan dibandingkan dengan laju pertumbuhan panjangnya. 


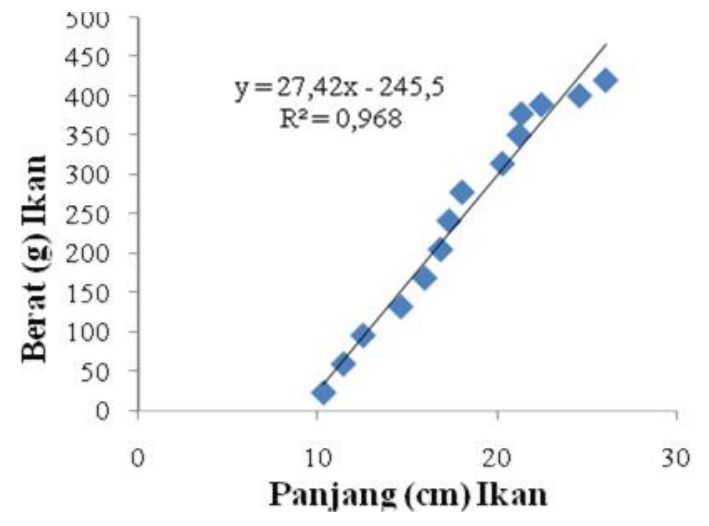

Gambar 3. Grafik laju pertumbuhan hubungan dengan berat ikan kerapu macan budidaya KJA IMTA.

Hubungan panjang berat ikan kerapu macan yang diperoleh dari sekitar kawasan sea farming pada budidaya KJA IMTA mengikuti persamaan $W=27,42 \mathrm{x}-245,5$ dengan koefisien korelasi $R^{2}=0,968$ Hal ini menunjukan tingkat kepercayaan terhadap model ini sebesar $96,8 \%$. Hasil analisis regresi linear menghasilkan persamaan $\boldsymbol{Y}=27,42 \mathrm{x}-245,5$ sehingga didapat nilai $b$ adalah 27,42. Setelah dilakukan uji $t$ pada selang kepercayaan 95\%, diputuskan bahwa nilai $b$ sebesar 27,42 sifat alometrik positif, dengan kata lain laju pertumbuhan berat ikan kerapu di sekitar kawasan sea farming lebih dominan dibandingkan dengan laju pertumbuhan panjangnya.

Hasil nilai $b>3$ yang didapatkan di kedua lokasi penelitian (IMTA dan Monokultur) pada ikan bawal bintang artinya memiliki pola hubungan yang sama yaitu alometrik positif. Pola pertumbuhan ikan dapat diketahui dengan melakukan analisa hubungan panjang dengan beratnya. Berat dapat dianggap sebagai suatu fungsi dari panjang. Nilai praktis yang didapat dari perhitungan panjang dengan berat dapat di gunakan untuk menduga berat dari panjang ikan atau sebaliknya, keterangan mengenai pertumbuhan, bobot dan perubahan dari lingkungan (Effendie, 2002).
Pengukuran kualitas air dengan parameter fisika dan kimia sangat mutlak untuk budidaya ikan, karena sangat berpengaruh bagi pertumbuhan dan proses metabolisme ikan. Parameter yang diukur adalah konduktivitas, kecerahan, turbiditas, Dissolved Oxygen (DO), salinitas, $\mathrm{pH}$ dan temperatur .

Hasil pengukuran kualitas air dengan parameter fisika dan kimia yang didapatkan di kedua lokasi penelitian (IMTA dan Monokultur) adalah konduktivitas berkisar antara 4,53 - 5,05 mS/cm, kecerahan berkisar antara 23,21 - 25,50 mg/l, turbiditas berkisar antara 19,89 - 27,00 mg/l, Dissolved Oxygen (DO) berkisar pada 6,09-7,50 mg/L, salinitas berkisar antara 25,09 - 32,37ppt, pH berkisar antara 7,21 - 7,96 dan temperatur berkisar antara $29,33-31,40{ }^{\circ} \mathrm{C}$

\section{KESIMPULAN}

Berdasarkan hasil penelitian yang telah dilakukan dapat disimpulkan bahwa hubungan panjang dengan berat ikan bawal bintang (Trachinotus blochii) di kedua lokasi penelitian memperlihatkan pola pertumbuhan yang sama yaitu nilai $b>3$ adalah alometrik positif, artinya laju pertumbuhan berat ikan lebih dominan (cepat) di bandingkan laju pertumbuhan panjangnya.

\section{DAFTAR PUSTAKA}

Barrington, K., Chopin, $\mathrm{T}$ and Robinson, S.2009. Integrated multi-trophic aquaculture (IMTA) in marine temperate waters. In D. Soto (ed.). Integrated mariculture: a global review. FAO Fisheries and Aquaculture Technical Paper. 529:7-46.Rome

Effendie, M.I. 2002. Biologi Perikanan. Yayasan Pustaka Nusantara. Jakarta

Effendie, M.I. 1997. Biologi Perikanan. Yayasan Pustaka Nusantara. Yogyakarta. 92p

Putro, S.P., Widowati, Suhartana dan Muhammad, F. 2015.The application of integrated multi trophic aquaculture (IMTA) using stratified rounded cage (SDFNC) for aquaculture sustainability. Internat.J.Sci.Eng.9(2):85-89 